\title{
ADOPSI DAN PEMELIHARAAN ANAK DALAM HUKUM ISLAM
}

\author{
Syaifullah MS, Sarfika Datumula
}

\begin{abstract}
Adoption of children is one of the noble ways for couples who have not been blessed with children. The presence of an adopted child is expected to fill the lonely days of husband and wife, even sometimes many couples make their adopted children as a "lure" so that later they will have their own child. In Islamic law, in principle, an adopted child is not prohibited as long as it involves nurturing, educating and caring for him/her, however, the adopted child is not considered to become the heir or obtain inheritance if it is connected or associated with his/her legal position in Islamic law. Child is a person who must be protected from everything that can make it difficult for him/her, to be able to provide a good deed done by his/her parents, and with Hadhanah (the right to custody of a child under Sharia Law), it is very important that this Hadhanah is handed over to the mother because it is a job that requires a lot of responsibility and persistence in doing so.
\end{abstract}

\section{Keywords: Adoption, Fostering}

\section{PENDAHULUAN}

Keluarga merupakan media pendidikan utama bagi perkembangan anak, dalam rangka mengembangkan potensi diri baik lahir maupun batin dengan mengoptimalkan peran lingkungan keluarga sebagai lingkungan pendidikan. ${ }^{1}$ Peran orang tua yang paling penting adalah mendidik, mengajar, dan melatih anak. Mendidik berarti menularkan dan mengembangkan nilai-nilai kehidupan/ kepribadian. Mengajar berarti mentransmisikan dan mengembangkan ilmu pengetahuan dan teknologi. Sedangkan pelatihan berarti mengembangkan keterampilan pada anak asuh berdasarkan QS. Al-Kahfi [18] 66-70. ${ }^{2}$ Manusia

\footnotetext{
${ }^{1}$ Nur Afni dan Jumahir, Peranan Orang Tua Dalam Meningkatkan Prestasi Belajar Anak, Musawa: Journal for Gender Studies, Vol. 12 No. 1 (2020).

${ }^{2}$ Hairuddin Cikka dan Usman Hamid, Peran Panti Asuhan Almuhajirin Kota Palu Dalam Membentuk Karakter Religius Anak Ditinjau Dari Hukum Islam, Musawa: Journal for Gender Studies, Vol. 12 No. 1 (2020).
} 
dalam membangun upaya dalam peningkatan mutu dan martabat hidupnya, upaya yang paling utama yang dilakukan adalah dengan pendidikan. 3

Dalam atikel ini penulis akan mengemukakan tentang salah satu persoalan kebutuhan manusia, yakni khusus aspek pengangkatan anak dan beberapa cara pengangkatan anak. Karena pengangkatan anak dan anak angkat termasuk bagian substansi dari hukum perlindungan anak yang telah menjadi bagian dari hukum yang hidup dan berkembang dalam masyarakat sesuai dengan adat-istiadat dan motivasi yang berbeda-beda serta perasaan hukum yang hidup dan berkembang di masing-masing daerah, walaupun di Indonesia masalah pengangkatan anak tersebut belum diatur secara khusus dalam undang-undang. Dalam hukum Islam tidak mengenal pengangkatan anak dalam arti menjadi anak kandung secara mutlak, sedang yang ada hanya di perbolehkan atau suruhan untuk memelihara dengan tujuan memperlakukan anak dalam segi kecintaan pemberian "nafkah, pendidikan atau pelayanan dalam segala kebutuhan yang bukan memperlakukan sebagai anak kandung (nasab).

Sedangkan penetapan pengangkatan anak berdasarkan hukum Islam praktek pengadilan agama, berdasarkan pasal 171 huruf (h) Kompilasi Hukum Islam yang berlaku di Indonesia Inpres No I Tahun 1991 tanggal 10 Juni 1991, menetapkan bahwa "Anak angkat adalah anak yang dalam hal pemeliharaan untuk hidupnya sehari-hari, biaya pendidikan dan sebagainya beralih tanggung jawabnya dari orang tua asal kepada orang tua angkatnya berdasarkan putusan pengadilan.”

Definisi anak angkat dalam Kompilasi Hukum Islam tersebut, jika dibandingkan dengan definisi anak angkat dalam UU No. 23 Tahun 2002 tentang Perlindungan Anak, memiliki kesamaan substansi. Pasal 1 angka 9 dinyatakan bahwa "Anak Angkat adalah anak yang haknya dialihkan dari lingkungan kekuasaan keluarga orang tua, wali yang sah, atau orang lain yang bertanggung jawab atas perawatan,pendidikan, dan membesarkan anak tersebut, ke dalam

\footnotetext{
${ }^{3}$ Hairuddin Cikka, Strategi Komunikasi Guru Memotivasi Peserta Didik Dalam Meningkatkan Prestasi Belajar, Al-mishbah, Vol.15 No. 2 Juli - Desember 2019
} 
lingkungan keluarga orang tua angkatnya berdasarkan putusan atau penetapan pengadilan.

Syara' menginginkan perkawinan yang kekal antara suami dan istri, kecuali oleh suatu sebab yang tidak dapat dipertahankan lagi, yakni karena itu pula syara' mengikat perkawianan, tepapi tidak mempermudah perceraian. Syara' membenarkan dan mengizinkan.Oleh karena itu masalah hak mengasuh anak pada masa ikatan perkawinan mendapat perhatian lebih dari syara' lebih- lebih pasca perceraian dan termasuk dalam paket hukum keluarga. Dalam kitab- kitab fikih pemeliharaan anak ini disebut hadhanah. Pada penafsiran hadhanah baik syarat, macam, maupun pengertian masih banyak simpang siur untuk lebih jelasnya akan dijelaskan dalam pembahasan.

Pemeliharaan seorang anak sangat penting untuk dilaksanakan baik oleh ibunya ataupun dari bapaknya, akan tetapi sering kali terjadi pendidikan anak dinomer duakan dari sebuah pekerjaan yang di anggap lebih penting dan merupakan tuntutan hidup untuk dirinya dan keluarganya, sehingga tidak jarang terjadi pengasuhan, pendidikan seorang anak terlantar disebabkan karena keadaan yang tidak memungkankan atau bahkan dengan sengaja dikesampingkan.

\section{PEMBAHASAN}

\section{A. Pengertian Adopsi}

Adopsi mempunyai dua pengertian, yaitu:

1. Mengambil anak orang lain untuk diasuh dan dididik dengan penuh perhatian dan kasih sayang, dan diperlakukan oleh orang tua angkatnya seperti anaknya sendiri, tanda memberi status anak kandung kepadanya.

2. Mengambil anak orang lain untuk diberi status sebagai anak kandung sehingga ia berhak memakai nasab orang tua angkatnya dan mewarisi harta peninggalannya, dan hak-hak lainnya sebagai hubungan anak dengan orang tua. ${ }^{4}$

Pengertian kedua dari adopsi diatas adalah pengertian menurut istilah dikalangan agama dan adat di masyarakat. Dan adopsi menurut istilah ini telah membudaya dimuka bumi ini, baik sebelum islam maupun sesudah islam,

\footnotetext{
${ }^{4}$ Sahal Mahfudh, Solusi Problematika Aktual hukum Islam. (Surabaya:Khalista, 2011), 23
} 
termasuk di masyarakat Indonesia. Adopsi di Indonesia pada umumnya dilakukan dengan memakai upacara keagamaan dan dengan pengumuman dan penyaksian pejabat dan tokoh agama agar terang (clear) statusnya. Dan setelah selesai upacara adopsi, maka si anak menjadi anggota penuh dari dari kerabat yang mengangkatnya, dan terputus hak warisnya dengan kerabatnya yang lama, seperti di Bali. Di Sulawesi Selatan, ada hubungan waris dengan orang tua kandung dan keluarganya, dan ia tidak berhak sebagai ahli waris dari orang tua angkat dan keluarganya, tetapi ia bisa diberi hibah atau wasiat. Hukum waris semacam ini di Sulawesi Selatan adalah akibat pengaruh Islam yang cukup Kuat di daerah ini. ${ }^{5}$

Demikian pula di Jawa, anak angkat masih tetap menjadi ahli waris dari orang tua kandungnya dan keluarganya, dan ia pun berhak pula sebagai ahli waris dari orang tua angkatnya, tetapi hanya terbatas pada harta peninggalan selain barang-barang pusaka yang berasal dari warisan yang harus dikembalikan kepada kerabat si suami atau kerabat si istri. Menurut Al -Barry,, hak waris anak angkat di Jawa seperti tersebut (tidak penuh hak warisnya atas harta peninggalan orang tua angkat), adalah karena adopsi di Jawa itu bukan urusan kerabat dan pelaksanaannya tidak dibuat "terang", artinya tidak memakai upacara keagamaan dan disaksikan oleh pejabat dan tokoh agama Menurut Al -Barry, di Minagkabau tampaknya tidak ada adopsi. Dan kalau hal ini benar, berarti pengaruh agama Islam yang cukup kuat di daerah itu. ${ }^{6}$

\section{B. Adopsi Menurut Pandangan Hukum Islam}

Islam telah lama mengenal istilah tabbani, yang di era modern ini disebut adopsi atau pengangkatan anak. Rasulullah SAW bahkan mempraktikkannya langsung, yakni ketika mengangkat Zaid bin Haritsah sebagai anaknya.

Majelis Ulama Indonesia (MUI) sejak lama sudah memfatwakan tentang adopsi. Pada salah satu butir pertimbangannya, para ulama memandang, bahwa

\footnotetext{
${ }^{5}$ http://ustadzmudzoffar.wordpress.com//hukum-anak-angkat/ diakses pada tanggal 17 Desember 2020 2004), 34

${ }^{6}$ Zakaria Ahmad Al -Barry, Hukum Anak - Anak Dalam Islam (Bulan Bintang, Jakarta, ,
} 
Islam mengakui keturunan (nasab) yang sah, yaitu anak yang lahir dari perkawinan (pernikahan). Hanya saja, MUI mengingatkan ketika mengangkat (adopsi) anak, jangan sampai si anak putus hubungan keturunan (nasab) dengan ayah dan ibu kandungnya. Sebab, pengangkatan anak orang lain dengan status seperti anak kandung maka Islam melarang sejak turun Surah Al-Ahzab ayat 37:

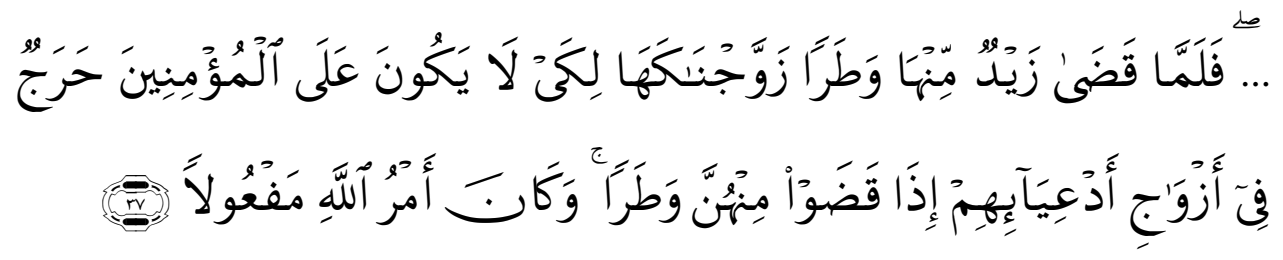

Terjemahnya:

“........Maka tatkala Zaid Telah mengakhiri keperluan terhadap Istrinya (menceraikannya), kami kawinkan kamu dengan dia supaya tidak ada keberatan bagi orang mukmin untuk (mengawini) isteri-isteri anak-anak angkat mereka, apabila anak-anak angkat itu Telah menyelesaikan keperluannya daripada isterinya dan adalah ketetapan Allah itu pasti terjadi". 7

Ayat ini merupakan rangkaian ayat-ayat Al-Qur'an yang menceritakan tentang kasus rumah tangga Zaid bin Haritsah dengan Zainab binti Jahasy. Zaid adalah bekas budak yang dimerdekakan oleh Nabi, kemudian dikawinkan dengan Zainab, yaitu saudara sepupu Nabi sendiri. Suami istri ini adalah orang-orang baik dan taat kepada agama. Namun rumah tangganya tidak bahagia. Sebab Zainab berasal dari kalangan bangsawan, sedangkan Zaid adalah bekas budak, meskipun Islal tidak mengenal diskriminasi berdasarkan ras, suku, bangsa dan sebagainay. Zaid menyadari hal itu (ketidakharmonisan rumah tangganya), maka ia mohon izin kepada Nabi untuk menceraikan Istrinya. Namun Nabi menyuruh ia untuk tetap mempertahankan rumah tangganya, dan ia pun mentaatinya. Namun setelah rumah tangga Zaid tetap tidak harmonis dan semua sahabat dan masyarakat tahu, maka akhirnya perceraian Zaid dan Zainab diizinkan, dan bahkan setelah habis idahnya, Nabi diperintahkan oleh Allah untuk mengawini Zainab, bekas istri anak angkatnya. ${ }^{8}$

\footnotetext{
452

${ }^{7}$ Departemen Agama RI, Alqur'an dan Terjemahnya (Semarang: CV. Toha Putra, 1989),

${ }^{8}$ Zaini Muderis, Adopsi, Suatu Tinjauan Dari Tiga Sistem Hukum (Jakarta: Sinar Grafika, 2007), 87
} 
Surah Al-Ahzab ayat 37 yang menerangkan kasus Zaid dengan Zainab diatas adalah untuk menegaskan bahwa:

1. Adopsi seperti praktek dan tradisi di zaman Jahiliyah yang memberi status kepada anak angkat sama dengan status anak kandung tidak dibenarkan (dilarang) dan tidak diakui oleh Islam.

2. Hubungan anak angkat dengan orang tua angkat dan keluarganya tetap seperti sebelum diadopsi, yang tidak mempengaruhi kemahraman dan kewarisan, baik anak angkat itu diambil dari intern kerabat sendiri, seperti di Jawa, kebanyakan kemenakan sendiri diambil sebagai anak angkatnya, maupun diambil dari luar lingkungan kerabat. ${ }^{9}$

\section{Tata Cara Mengadopsi Anak}

Surat Edaran Mahkamah Agung RI No.6/83 yang mengatur tentang cara mengadopsi anak menyatakan bahwa untuk mengadopsi anak harus terlebih dahulu mengajukan permohonan pengesahan/pengangkatan kepada Pengadilan Negeri di tempat anak yang akan diangkat itu berada. Bentuk permohonan itu bisa secara lisan atau tertulis, dan diajukan ke panitera. Permohonan diajukan dan ditandatangani oleh pemohon sendiri atau kuasanya, dengan dibubuhi materai secukupnya dan dialamatkan kepada Ketua Pengadilan Negeri yang daerah hukumnya meliputi tempat tinggal/domisili anak yang akan diangkat .

Adapun Syarat-syaratnya yaitu:

1. Seorang laki-laki yang sudah atau pernah menikah, tetapi tidak mempunyai anak laki-laki.

2. istri bersama-sama.

3. Seorang wanita yang telah menjadi janda, dengan ketentuan tidak ada larangan untuk melakukan pengangkatan anak oleh almarhum suaminya dalam wasiat yang ditinggalkannya dan ia tidak telah kawin lagi. ${ }^{10}$

Selain syarat-syarat tersebut di atas maka diperlukan pula kata sepakat (persetujuan) dari orang-orang yang bersangkutan:

1. Apabila yang diangkat itu seorang anak sah, maka ada kata sepakat dari kedua orang tuanya.

2. Jika yang diangkat itu seorang anak diluar kawin, tetapi diakui oleh kedua orang tuanya, maka diperlukan persetujuan dari kedua orang tua tersebut.

\footnotetext{
${ }^{9}$ Andi Syamsu Alam dan M. Fauzan, Hukum Pengangkatan Anak Perspektif Islam (Jakarta: Kencana Prenada Media Group, 2008), 54

${ }^{10}$ Surat Edaran Mahkamah Agung RI No.6/83 Yang Mengatur Tentang Cara Mengadopsi Anak
} 
3. Bagi anak yang telah berumur 15 tahun, kata sepakat diperlukan juga dari anak yang bersangkutan, apakah anak yang akan di angkat itu bersedia atau tidak.

4. Bagi seorang wanita janda yang akan melakukan pengangkatan anak, maka diperlukan kata sepakat dari para saudara laki-laki yang telah dewasa dan bapak mendiang suaminya. Apabila mereka tidak ada atau tidak berkediaman di Indonesia, cukup kata sepakat dari dua orang tua diantara keluarga sedarah laki-laki yang terdekat dari pihak bapak si suami yang telah meninggal dunia itu sampai dengan derajat ke empat, yang telah dewasa dan bertempat tinggal di Indonesia. ${ }^{11}$

Disamping itu perbedaan umur antara anak yang akan di angkat dengan ayah angkatnya, sekurang-kurangnya 18 tahun dan dengan ibunya sekurangkurangnya 15 tahun Dalam kitab Undang-undang Hukum Perdata (BW), kita tidak menemukan satu kesatuan yang mengatur masalah pengangkatan anak. Hanya mengenai pengakuan terhadap anak-anak luar nikah mengenai pengakuan terhadap anak-anak luar nikah dalam Buku 1BW bab XII bagian ketiga. Kita tidak menemukan satu ketentuan yang mengatur masalah adopsi atau anak angkat ini, yang ada hanyalah ketentuan-ketentuan tentang pengakuan anak diluar kawin, yaitu seperti yang diatur dalam buku 1BW bab XII bagian ketiga, pasal 280 sampai 289, tentang pengakuan terhadap anak-anak luar kawin. Ketentuan ini boleh dikatakan tidak ada sama sekali hubungan denagn masalah adopsi ini. Oleh karena kitab undang-undang Hukum perdata tidak mengenal hal pengangkatan anak ini. ${ }^{12}$

\section{Pemeliharaan Anak (Hadhanah)}

\section{Pengertian Pemeliharaan Anak (Hadhanah)}

Hadhanah secara bahasa, berarti meletakkan sesuatu di dekat tulang rusuk atau di pangkuan, karena Ibu waktu menyusukan anaknya meletakkan anak itu di pangkuannya, seakan-akan Ibu disaat itu melindungi dan memelihara anaknya sehingga "Hadhanah" dijadikan istilah yang maksudnya; pendidikan dan

\footnotetext{
${ }^{11}$ Surat Edaran Mahkamah Agung RI No.6/83 Yang Mengatur Tentang Cara Mengadopsi Anak

${ }^{12}$ Kitab Undang-Undang Hukum Perdata (BW) Dalam Buku 1BW Bab XII Bagian Ketiga, Pasal 280 Sampai 289
} 
pemeliharaan anak sejak dari lahir dari lahir sampai sanggup berdiri sendiri, yang dilakukan oleh kerabat anak itu sendiri. ${ }^{13}$

Para Ulama' Fiqih mendifinisikan; Hadhanah sebagai tindakan pemeliharaan anak-anak yang masih kecil, baik laki-laki atau perempuan atau yang sudah besar tetapi belum Mumayyiz, menyediakan sesuatu yang menjadikan kebaikanya, menjaganya dari sesuatu yang menyakiti, mendidik jasmani dan rohani, agar mampu berdiri sendiri serta bisa mengemban tanggung jawab. ${ }^{14}$

\section{Dasar Hukum Pemeliharaan Anak (Hadhanah)}

Hadhanah (pengasuhan anak) hukumnya wajib, karena anak yang masih memerlukan pengasuhan ini akan mendapatkan bahaya jika tidak mendapatkan pengasuhan dan perawatan, sehingga anak harus dijaga agar tidak sampai membahayakan. Selain itu ia juga harus tetap diberi nafkah dan diselamatkan dari segala hal yang dapat merusaknya. ${ }^{15}$

Dasar hukum ini disebutkan dalam Al-Qur'an surat At-Tahrim, sebagaimana firman Allah yang berbunyi;

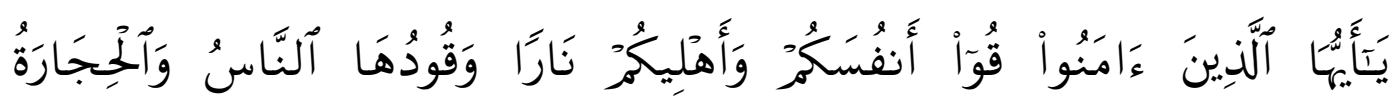

Terjemahnya; hai orang-orang yan beriman, peliharalah dirimu dan keluargamu dari api neraka yang bahan bakarnya adalah manusia dan batu. (QS. Al-Tahrim: 6). ${ }^{16}$

Sudah jelas kiranya dalam ayat ini para orang tua diperintahkan Allah SWT. untuk memelihara keluarganya dari api neraka, dengan berusaha agar seluruh anggota keluarganya itu melaksanakan perintah-perintah tuhan dan menjauhi larangannya, dan dalam ayat ini yang disebut keluarga adalah seorang anak. ${ }^{17}$ Ada banyak hal yang perlu ditanamkan pada setiap anak sejak kecil, di antaranya yang terpenting adalah agama, karena apabila diperkenalkan dengan agama, maka moral mereka akan terbentuk menjadi seorang anak yang agamis. Dalam hal

\footnotetext{
${ }^{13}$ https://imamrusly.wordpress.com/hadhanah-, Diakses 16 Desember 2020

${ }^{14}$ Musthafa Kamal Pasha, Chalil, dan Wahardjani, Fikih Islam (Jogyakarta: Citra Karsa Mandiri, 2002), 304

${ }^{15}$ Ibid.

${ }^{16}$ Departemen Agama RI, Alqur'an, 951

${ }^{17}$ Hakin Rahmat, Hukum Perkawinan Islam (Bandung: Pustaka Setia, 2000), 224
} 
ini, kita tidak boleh menafikan kekuatan agama, karena dengan agama manusia bisa membedakan antara yang benar dan yang salah, serta dengan agama pula kita bisa tahu tentang cara hidup yang benar. ${ }^{18}$ Seorang Hadhanah (Ibu) yang Menangani dan Menyelenggrakan Kepentingan Anak Kecil yang Diasuhnya, yaitu Kecakapan dan Kecukupan.

Kecukupan dan kecakapan juga memerlukan syarat-syarat tertentu. Jika syarat-syarat tertentu ini tidak terpenuhi satu saja maka gugurlah kebolehan menyelenggarakan Hadhanahnya.

\section{Syarat-syarat Pemeliharaan Anak (Hadhanah)}

Adapun Syarat-Syarat Hadhanah Sebagai berikut:

a. Berakal Sehat, jadi bagi orang yag kurang akal seperti gila, keduanya tidak boleh menangani Hadhanah. Karena mereka tidak dapat mengurusi dirinya sendiri, sebab itu ia tidak boleh diserahi mengurusi orang lain. Sebab orang yang punya apa-apa tentulah ia tidak punya apa-apa untuk diberikan kepada orang lain.

b. Dewasa, sebab anak kecil sekalipun Mumayyiz, tetapi ia tetap membutuhkan orang lain yang mengurusi urusannya dan mengasuhnya, karena itu dia tidak boleh menangani urusan orang lain.

c. Mampu Mendidik, karena itu tidak boleh menjadi pengasuh orang yang buta atau rabun, sakit menular atau sakit yang melemahkan jasmaninya untuk mengurus kepentingan anak kecil, tidak berusia lanjut, yang bahkan ia sendiri juga perlu diurus oleh orang lain.

d. Amanah dan Berbudi, sebab orang yang curang tidak aman bagi anak kecil dan tidak dapat dipercaya akan dapat menunaikan kewajibannya dengan baik. Bahkan nantinya si anak dapat meniru atau berkelakuan seperti orang yang curang itu.

e. Islam, anak Muslim tidak boleh diasuh oleh orang yang bukan Muslim, sebab Hadhanan adalah masalah perwalian. Sedangkan Allah tidak

${ }^{18}$ Aldiawan, Dakwah Dalam Mengatasi Problematika Remaja, Al-mishbah, Vol.16 No. 1 Januari - Juni 2020, 44. 
10 | MUSAWA, Vol. 13 No.1 Juni $2021: 1-19$

membolehkan orang mukmin dibawah perwalian orang kafir. ${ }^{19}$ Hal ini berdasar pada firman Allah dalam surat Annisa' ayat 141:

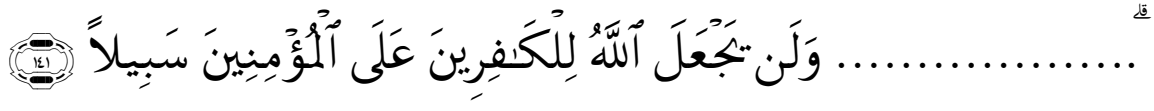

Terjemahnya: dan Allah tidak akan memberikan jalan kepada orang orang kafir menguasai orang orang mukmin. (QS. Annisa': 141). ${ }^{20}$

f. Ibunya tidak kawin lagi, jika si ibu telah kawin lagi dengan laki-laki lain.

g. Merdeka, sebab seorang budak biasanya sangat sibuk dengan urusan-urusan tuannya, sehingga ia tidak punya kesempatan untuk mengasuh anak kecil. ${ }^{21}$

\section{E. Yang Berhak Dalam Pemeliharaan Anak (Hadhanah)}

Para Ulama' berbeda pendapat tentang siapa yang berhak terhadap Hadhanah, apakah yang berhak itu Hadhin atau Mahdhun (anak). Sebagian pengikut Madzhab Hanafi berpendapat bahwa Hadhanah itu merupakan hak anak, sedangkan menurut Syafi;i, Ahmad, dan sebagian pengikut Madzhab Maliki berpendapat bahwa yang berhak terhadap Hadhanah itu adalah Hadhin.

Jika memerhatikan maksud ayat-ayat Al-Qur'an dan Hadist, maka dapat dipahami bahwa, Hadhanah itu disamping hak Hadhin, Hadhanah juga merupakan hak Mahdhun (anak). Dari itu Hadhin berhak mendapatkan pahala dari anaknya meskipun ia telah meninggal dunia, jika ia berhasil mendidik anaknya menjadi orang yang taqwa dikemudian hari.

Dasarnya adalah Hadist sebagai berikut;

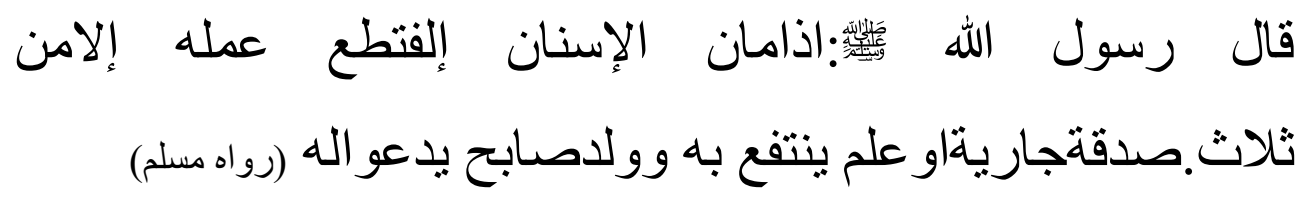

Artinya: Rasulullah SAW. Bersabda "apabila seorang manusia meninggal dunia putuslah amalnya, kecuali tiga perkara, pahala dari shadaqah jariyah,

\footnotetext{
${ }^{19}$ Abdul Rahmad Ghazaly, Fikih Munakahat (Bogor; Kencana,2003), 189- 190

${ }^{20}$ Departemen Agama RI, Alqur'an, 115

${ }^{21}$ Sayyid Sabid, Fiqih Sunnah, vol 8 (Bandung, PT.Al-Ma'arif, 1980), 179-184
} 
atau pahala dari ilmu yang bermanfaat, dan anak shaleh yang selalu mendoakan"(HR. Muslim). ${ }^{22}$

Dasar urutan orang yang berhak melakukan Hadhanah dari empat Madhab adalah:

\section{Kalangan Madzhab Syafi' $i$}

berpendapat bahwa hak anak asuh dimulai dari

$\checkmark$ Ibu kandung.

$\checkmark$ Nenek dari pihak ibu.

$\checkmark$ Nenek dari pihak ayah.

$\checkmark$ Saudara perempuan.

$\checkmark$ Bibi dari pihak ibu.

$\checkmark$ Anak perempuan dari saudara laki-laki.

$\checkmark$ Anak perempuan dari saudara perempuan.

$\checkmark$ Bibi dari pihak ayah. ${ }^{23}$

\section{Kalangan Madzhab Hanafi}

Berpendapat bahwa orang yang palin berhak mengasuh anak adalah

$>$ Ibu kandungnya sendiri.

Nenek dari pihak ibu.

Nenek dari pihak ayah.

Saudara perempuan (kakak perempuan).

Bibi dari pihak ibu.

Anak perempuan saudara perempuan.

Anak perempuan saudara laki-laki.

Bibi dari pihak ayah. ${ }^{24}$

\section{Kalangan Madzhab Maliki}

Berpendapat bahwa urutan hak anak asuh dimulai dari sebagai berikut:

$\checkmark$ Ibu kandung.

$\checkmark$ Nenek dari pihak ibu.

$\checkmark$ Bibi dari pihak ibu.

${ }^{22}$ Ibid, 192

${ }^{23}$ Muhammad Jawad Mughniyah, Fikih 5 mazdab, ( Jakarta; Lentera, 2002), 417-418

${ }^{24}$ Ibid., 
12 | MUSAWA, Vol. 13 No.1 Juni 2021 : 1-19

Nenek dari pihak ayah.

$\checkmark$ Saudara perempuan.

Bibi dari pihak ayah.

Anak perempuan dari saudara laki-laki.

$\checkmark$ Penerima wasiat.

$\checkmark$ Dan kerabat lain (ashabah) yang lebih utama. ${ }^{25}$

\section{Kalangan Madzhab Hanbali}

Berpendapat bahwa urutan hak anak asuh dimulai dari sebagai berikut:

$>$ Ibu kandung.

$>$ Nenek dari pihak ibu.

Kakek dan ibu kakek.

Bibi dari kedua orang tua.

Saudara Perempuan Se Ibu.

Saudara perempuan seayah.

Bibi dari ibu kedua orangtua.

Bibinya ibu.

Bibinya ayah.

Bibinya ibu dari jalur ibu.

Bibinya ayah dari jalur ibu.

Bibinya ayah dari pihak ayah.

Anak perempuan dari saudara laki-laki.

Anak perempuan dari paman ayah dari pihak ayah.

Kemudian kalangan kerabat dari urutan yang paling dekat. ${ }^{26}$

Urutan yang berhak dalam Hadhanah ini memang lebih dekat kepada seorang ibu atau wanita berdasarkan sabda Rasulullah yang diriwayatkan oleh Abu Dawud dan Hakim, yang bercerita bahwa seorang wanita telah datang mengadukan masalahnya kepada Rasulullah SAW. Perempuan itu berkata, "saya telah diceraikan oleh suami saya, dan anak saya akan diceraikannya dari saya."

\footnotetext{
25 Ibid.,

${ }^{26}$ Ibid.,
} 


\section{F. Masa Pemeliharaan Anak (Hadhanah)}

Dalam masalah masa atau waktu ini dalam Al-Qur'an tidak dijelaskan secara jelas, hanya saja terdapat isyarat-isyarat yang menerangkan ayat tersebut, sehingga para Ulama' berijtihad sendri-sendiri dalam menetapkan dengan berpedoman kepada isyarat itu. Seperti menurut Imam Hanafi, masa Hadhanah anak laki-laki berakhir ketika anak itu tidak lagi memerlukan penjagaan dan dapat mengurus keperluannya sehari-hari, seperti makan, minum, mengatur pakaian, dan lain sebagainya. Sedangkan untuk perempuan berakhir apabila sudah baligh atau telah datang haid pertama.

Sedangkan pengikut pada generasi akhir menetapkan bahwa masa Hadhanah itu berakhir umur 19 tahun bagi anak laki-laki. Dan 11 tahun umtuk seorang perempuan. Menurut Imam Syafi'i berpendapat bahwa masa Hadhanah itu berakhir setelah anak itu sudah Mumayyiz, yakni berumur 5 tahun dan 6 tahun. ${ }^{27}$ Dengan berdasar pada Hadits:

Artinya: Rasulullah SAW bersabda:"anak ditetapkan antara bapak dan ibunya sebagaimana anak(anak yang belum mumayyiz) perempuan ditetapkan antara ibu bapaknya.

Akan tetapi menurut undang-undang mesir tidak ada masalah dalam masa Hadhanah Selagi anak tersebut berada di antara ibu bapaknya, hanya saja masa Hadhanah itu terjadi apabila terjadi perceraian dan terdapat perbedaan pendapat antara keduanya, maka masa Hadhanah diserahkan kepada kebijakan hakim dengan ketentuan minimal 7 tahun dan maksimak 9 tahu, akan tetapi meskipun demikan kemaslahatan anak itu lebih diutamakan. ${ }^{28}$ Lain halnya dengan batas hadhanah menurut Undang-undang pasal 98 yang menjelaskan bahwa batas usia berdiri sendiri atau dewasa adalah 21 tahun, sepanjang anak itu tidak cacat fisik maupun mental atau belum pernah melangsungkan perkawinan. ${ }^{29}$

\footnotetext{
${ }^{27}$ Ibid, 220

${ }^{28}$ Ibid, 224-225

${ }^{29}$ Rofiq Ahmad, Hukum Islam di Indonesia, (PT Raja Grafindo Persada, Jakarta, 1998),
} 
14 | MUSAWA, Vol. 13 No.1 Juni 2021 : 1-19

\section{G. Upah Pemeliharaan Anak (Hadhanah)}

Seorang ibu tidak berhak menerima upah Hadhanah dan menyusui, selama ia masih menjadi istri dari ayah anak kecil itu, atau selama masih dalam masa Iddah. Karena dalam keadaan tersebut ia masih mempunyai nafkah sebagai istri atau nafkah masa Iddah. ${ }^{30}$ Hal ini sesuai dengan firman Allah dalam surat AlBaqarah ayat 233:

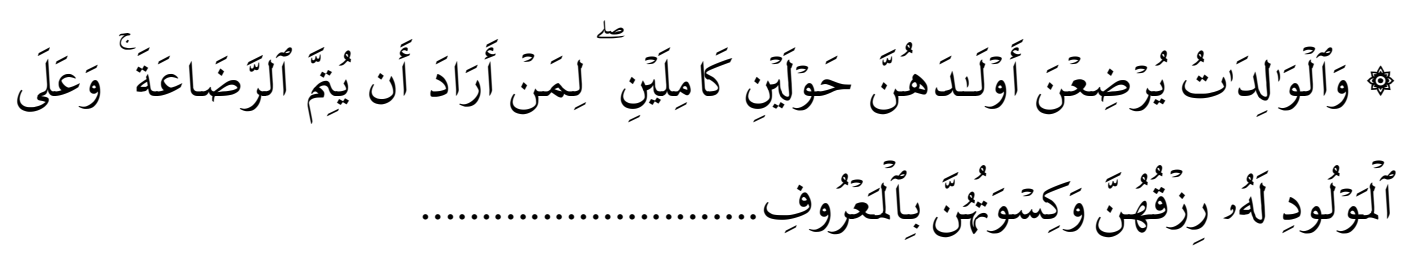

Terjemahnnya : para ibu hendaklah menyusukan anak-anaknya selama 2 tahun penuh, yaitu bagi yang ingin menyempurnakan penyusuan. Dan kewajiban ayah memberi makan dan pakaian kepada para ibu dengan cara yang makruf. (QS. AL-Baqarah: 233). ${ }^{31}$

Adapun sesudah masa Iddahnya, maka ia berhak atas upah itu seperti haknya kepada upah menyusui, Allah SWT, berfirman dalam surat At-Thalaq ayat 6:

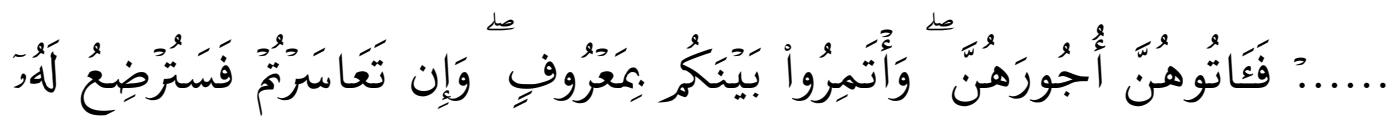

Terjemahnya: maka berikanlah upah kepada merreka upahnya, dan musyawarahkanlah di antara kamu (segala sesuatu) dengan baik, dan jika kamu menemui kesulitan maka perempuan lain boleh menyusukan anak itu, untuknya. (QS. AT-Thalaq:6). ${ }^{32}$

Karena wanita yang sudah sampai masa Iddahnya, disamakan dengan seorang yang bekerja untuk orang lainnya, dan ayah dari anak itu berkewajiban untuk membayar upah tersebut.

\footnotetext{
${ }^{30}$ Hakim, Hukum, 246

${ }^{31}$ Departemen Agama RI, Al-qur'an, 57

${ }^{32}$ Ibid, 946
} 


\section{H. Macam- Macam Pemeliharaan Anak (Hadhanah)}

Hadhanah merupakan kebutuhan atau keharusan demi kemaslahatan anak itu sendiri, sehingga meskipun kedua orang tua mereka memiliki ikatan atau sudah bercerai anak tetap berhak mendapatkan perhatian dari kedua anakanya.

\section{Hadhanah Pada Masa Perkawinan.}

UUP No. 1 tahun 1974 pasal 45, 465, 47 sebagai berikut: Pasal 45:

1. Kedua orang tua wajib memelihara dan mendidik anak mereka sebaikbaiknya.

2. Kewajiban orang tua yang dimaksud dalam ayat 1 pasal ini berlaku sampai anak itu kawin atau berdiri sendiri berlaku terus meski perkawinan antara orang tua putus.

Pasal 46:

1. Anak wajib menghormati orang tua dan menaati kehendak mereka dengan baik.

2. Jika anak telah dewasa, ia wajib memelihara menurut kemampuannya, orang tua dan keluarga dalam garis lurus ke atas, bila mereka memerlukan batuannya.

\section{Pasal 47:}

1. Anak yang belum mencapai umur 18 tahun atau belum pernah melangsungkan perkawinan ada di bawah kekuasaan orang tuanya, selama mereka tidak dicabut dari kekuasaanya.

2. Orang tua mewakili anak tersebut mengenai perbuatan hukum di dalam dan di luar pengadilan.

Dalam hal ayat 1 Pasal 47, 49 menyebutkan bahwa kekuasaan salah satu atau kedua orang tuanya dicabut dari anaknya atas permintaan orang tua lain, keluarga anak dalam garis lurus ke atas dan saudara kandung yang telah dewasa atau pejabat yang berwenang dengan keputusan pengadilan meskipun dicabut mereka tetap berkewajiban. ${ }^{33}$

Namun demikian orang tua masih memiliki kewajiban atas biaya pemeliharaan anak tersebut (ayat 2) berkaitan dengan pemeliharaan anak juga, orang tua pun mempunyai tanggung jawab yang berkaitan dengan kebendaan.

\footnotetext{
${ }^{33}$ UUP No. 1 tahun 1974 pasal 45, 465, 47
} 
16 | MUSA WA, Vol. 13 No.1 Juni 2021 : 1-19

Dalam pasal 106 disebutkan bahwa orang tua berkewajiban merawat dan mengembangkan harta anaknya yang belum dewasa atau di bawah pengampuan. Dan orang tua bertanggung jawab atas kerugian yang ditimbulkan karena kesalahan dan kelalaian dari kewajiban. ${ }^{34}$

Ditambah dengan pasal 98 dan 99 tentang pemeliharaan anak :

Pasal 98 :

1. Batas usia anak yang mampu berdiri sendiri atau dewasa 21, sepanjang tidak cacat fisik atau mental.

2. Orang tuanya mewakili anaknya tersebut mengenai segala perbuatan.

3. PA (Pengadilan Agama) dapat menunjuk kerabat terdekat yang mampu bila orangtuanya tidak mampu.

Pasal 99 : Anak yang sah adalah :

-Anak yang dilahirkan dalam atau akibat perkawinan yang sah hasil dari perbuatan suami istri yang sah di luar rahim dan dilahirkan oleh istri tersebut. $^{35}$

\section{Hadhanah Pada Masa Perceraian}

Perceraian bukanlah halangan bagi anak untuk memperoleh hak pengasuhan atas dirinya dan kedua orang tuanya, sebagaimana yang telah diatur pada UUP NO.1 thn 1974 Pasal 41 tentang akibat putusnya perkawinan karena perceraian adalah:

1. Baik ibu atau bapak tetap berkewajiban memelihara, mendidik anakanaknya, semata-mata berdasarkan kepentingan anak bilaman ada perselisihan mengenai pengasuhan anak bilamana ada perselisihan mengenai pengasuhan anak-anak, pengadilan memberi keputusan;

2. Bapak yang bertanggung jawab atas semua biaya pendidikan dan pemeliharaan, bilamana bapak dalam kenyataannya tidak dapt memenuhi kewajiban tersebut, pengadilan dapat menentukan bahwa ibu ikut memikul biaya tersebut.

3. Pengadilan dapat mewajibkan kepada bekas suami untuk memberikan biaya penghidupan dan menentukan suatau kewajiban bagi bekas istri. ${ }^{36}$

Dan diatur juga dalam KHI pada pasal 105 dalam permasalahan perceraian, yang mana anak pada saat itu belum mumayyiz yaitu:

1. Belum berumur 12 tahun masih haknya seorang ibu.

\footnotetext{
${ }^{34}$ UUP No. 1 tahun 1974 pasal pasal 106

${ }^{35}$ UUP No. 1 tahun 1974 pasal pasal 98-99

${ }^{36}$ UUP NO.1 thn 1974 Pasal 41
} 
2. Ketika sudah mumayyiz disrahkan kepada anaknya untuk memilih diantara kedua orang tuanya sebagai pemegang hak pemeliharaannya.

3. Biaya pemeliharaan di tanggung oleh ayah.

\section{KESIMPULAN}

Adopsi anak adalah salah satu cara mulia bagi pasangan yang belum dikaruniai anak. Kehadiran anak adopsi diharapkan dapat mengisi hari-hari sepi pasangan suami istri tersebut, bahkan tak jarang banyak pasangan yang menjadikan anak adopsi sebagai “pancingan” agar kelak mereka memiliki keturunan kandung mereka sendiri. Dalam hukum Islam pada prinsipnya anak angkat itu tidak dilarang sepanjang hal itu menyangkut memelihara, mendidik dan mengasuhnya akan tetapi anak angkat itu tidak dikenal bila dihubungkan atau dikaitkan dengan kedudukan hukumnya dalam hal ini apabila menjadi ahli waris atau memperoleh kewarisan.

Anak adalah seorang yang wajib untuk dilindungi dari segala yang dapat menyulitkan dirinya, untuk dapat memberikan suatu kebaikan yang dilakukna oleh kedua orang tuanya, dan dengan adanya Hadhanah sangat penting kiranya Hadhanah ini diserahkan kepada pihak ibu, karena Hadhanah ini merupaka pekerjaan yang membutuhkan sangat tanggung jawab dan ketelatenan dalam melakukannya. Dan kenapa sebabnya perempuan itu lebih berhak dari pada lakilaki, karena perempuan lebih pantas dalam hal urusan ini. Lebih pandai, lebih sabar dan lebih cinta kepada anak-anaknya, sesuai dengan sabda-sabda Nabi yang telah dijelaskan diatas. Dan semua yang tersebut diatas adalah apabila anak itu belum baligh yaitu umur 15 tahun, apabila ia sudah baligh, maka lebih baik segala urusannya diserahkan kepada dirinya sendiri. 
18 | MUSAWA, Vol. 13 No.1 Juni $2021: 1-19$

\section{DAFTAR PUSTAKA}

Afni, Nur dan Jumahir, Peranan Orang Tua Dalam Meningkatkan Prestasi Belajar Anak, Musawa: Journal for Gender Studies, Vol. 12 No. 1 (2020).

Ahmad Al -Barry, Zakaria . Hukum Anak - Anak Dalam Islam. Jakarta: Bulan Bintang, 2004

Aldiawan, Dakwah Dalam Mengatasi Problematika Remaja, Al-mishbah, Vol.16 No. 1 Januari - Juni 2020, 44.

Cikka, Hairuddin dan Hamid, Usman. Peran Panti Asuhan Almuhajirin Kota Palu Dalam Membentuk Karakter Religius Anak Ditinjau Dari Hukum Islam, Musawa: Journal for Gender Studies, Vol. 12 No. 1 (2020).

Cikka, Hairuddin. Strategi Komunikasi Guru Memotivasi Peserta Didik Dalam Meningkatkan Prestasi Belajar, Al-mishbah, Vol.15 No. 2 Juli Desember 2019

Departemen Agama RI, Al-Qur'an dan Terjemahnya. Semarang: CV. Toha Putra, 1989

http://ustadzmudzoffar.wordpress.com//hukum-anak-angkat/ diakses pada tanggal 17 Desember 2020

https://imamrusly.wordpress.com/2012/04/22/hadhanah-, Diakses 17 Desember 2020

Jawad Mughniyah, Muhammad. Fikih 5 mazdab. Jakarta; Lentera, 2002

Kamal Pasha, Musthafa Chalil, dan Wahardjani. Fikih Islam. Jogyakarta; Citra Karsa Mandiri, 2002

Muderis, Zaini. Adopsi, Suatu Tinjauan Dari Tiga Sistem Hukum. Jakarta: Sinar Grafika, 2007

Rahmad Ghazaly, Abdul. Fikih Munakahat. Bogor; Kencana, 2003

Rahmat, Hakim. Hukum Perkawinan Islam. Bandung; Pustaka Setia, 2000

Rasyid, Sulaiman. Fiqih Islam. Bandung, sinar Baru Al Gensindo, 1986

Rofiq, Ahmad. Hukum Islam di Indonesia. PT Raja Grafindo Persada, Jakarta, 1998

Sabid, Sayyid. Fiqih Sunnah, vol 8. Bandung, PT.Al-Ma'arif, 1980 
Syaifullah, Adopsi dan Pemeliharaan Anak ... $\mid 19$

Surat Edaran Mahkamah Agung RI No.6/83 Yang Mengatur Tentang Cara Mengadopsi Anak

Syamsu Alam, Andi dan M. Fauzan. Hukum Pengangkatan Anak Perspektif Islam. Jakarta: Kencana Prenada Media Group, 2008.

UUP No. 1 tahun 1974 